\title{
Entrepreneurial Development in Handloom Sector through Effective Strategy Formulation:An Empirical Study in Odisha, state of India
}

\begin{abstract}
The handloom sector is yet to produce an ample size of entrepreneurship despite its potential in the globalization era. However, even after continuous intervention by the Government and other entities, the sector has miserably failed in creating an entrepreneurial climate for the community. The study identifies numerous factors responsible for these conditions and suggests suitable interventions and strategies to alter the situation that exists. Therefore, two prominent handloom clusters have been taken in India and the primary study was conducted in both the clusters using a qualitative approach. The findings of the study reveal a that number of skilled and semi-skilled weavers express to join as an entrepreneur if their issues and development factors like better credit system, a research center for trend forecasting at the local level, technological upgradation, regular quality training, feeling of ownership of stakeholders, and incubation center, etc., could be taken care of by the Government and other private-entity companies and NGOs. Besides, most of the master weavers claim that lack of getting entrepreneurial status is debarred from the government benefits although they are already into handloom enterprises. Although the Government has many schemes for their upliftment, not a single weaver from the communities, has registered himself as a business entity under the companies' act or even operate as a sole proprietor. So, there is an opportunity for entrepreneurship in the cluster if impeding issues are considered and implemented.
\end{abstract}

Keywords: Handloom, Technology, fashion \& influencing factor, liberalization, and rural industrialization
Volume 6 Issue 4 - 2020

Santosh Tarai

Associate Professor, NIFT, Bhubaneswar, India

Correspondence: Dr. Santosh Tarai, Associate Professor, NIFT, Bhubaneswar, India, Email santosh.tarai@nift.ac.in

Received: June 16,2020 | Published: July 24, 2020

\section{Introduction}

The word 'Handloom' is quite synonymous with our very own country India, which is the ultimate storehouse of numerous jawdropping handcrafted beauties which the world sees in awe. It is one of the oldest and largest cottage industries in India with excellent craftsmanship. Indian handloom crafts are diverse and have a rich history and heritage since its inception. It provides livelihood and employment opportunities to millions of people in India, particularly in rural areas in the non-farm sector. Due to its richness in craft and design that is embedded with the diversity of Indian culture produces a wide range of products, so, it plays a vital role to check rural-urban migration. Therefore, this sector is considered as one of the important drivers of the Indian rural economy and contributes significantly to the national economy. Further, in the globalization and modernization era, this sector gains its fame and acclamation from all over the world by producing unique artistic work of weavers in product diversification, and setting up contemporary design.

Looking at the global scenario, India is leading in handloom production with $95 \%$ contribution. ${ }^{1}$ It seems that there is scope for weavers' products in the market in future being sustainable in nature. Similarly, many individual experience weavers are doing good business because of the market linkage developed by the Government initiatives and the extension programs. It is reported few numbers of master weavers across the handloom clusters in India are into the entrepreneurship. Due to their enterprise skill and activity, they have created seventy $70-80 \%$ jobs for the livelihood of weavers in the clusters. ${ }^{2}$ Further the study reveal that the existence of the weavers is primarily dependent upon master weavers or skilled weavers in their respective clusters.

The products developed by various handloom clusters in India are a representation of diversity in the country. For instance, Kalamkari is a type of hand-painted or block-printed cotton textile, produced in Andhra Pradesh and Telangana state and this cluster use only natural dyes in Kalamkari and it involves twenty-three steps for making the products. Pochampally sari, from Telangana state and the weavers use traditional geometric patterns in Ikat style of dyeing. The Varanasi cluster from Uttar Pradesh state uses technique like gold and silver brocade or zari, fine silk and opulent embroidery particularly sarees and other apparels. Chanderi saris are produced from three kinds of fabric: pure silk, Chanderi cotton and silk cotton. Traditional coin, floral art, peacocks and geometric designs are woven into different Chanderi patterns from Madhya Pradesh state.

Clusters in Odisha have their own story to tell. Pasapali Saree is a handloom sari weaved mainly in the Bargarh, Subarnapur and Boudh district of Odisha. The name Pasapali is derived from pasa or gambling games using the Chess board. These saris have intricate check patterns of contrast colours resembling the chess boards which give it such name. Kotpad handloom is a natural like vegetable, root, bark dyed fabric woven by the tribal weavers of Kotpad, Odisha. This cluster produces saree and other contemporary products. Sambalpur cluster in Western Odisha, produces Sambalpuri saree uses the textile with a traditional handwoven ikat wherein the warp and the weft are tiedyed before weaving saree and other contemporary apparel. Gopalpur cluster is famous for producing Tussar fabrics, this cluster uses very 
unique features of 'Peduncle' of the silkworm's cocoon to create yarn and make home textile products, sarees, bedsheets, dress linings and shawls etc. This cluster also creates 'Ahimsa Silk' made from Ghicha yarn which showcases the efficient craftsmanship of the weavers of the cluster as it is one of the most demanded products of the cluster by many retailers. Maniabandha or khandua- it is a traditional "bandha" or ikat sari produced from Nuapatna cluster, Odisha and worn by women during wedding. Apart from the traditional products, these clusters are also producing different types of contemporary apparels due to globalisation of cultural and changing of lifestyle.

Considering the positive side of the clusters, the paper attempts to study two prominent handloom clusters of Odisha i.e., Bargarh and Gopalpur. It aims to discuss the textile life of weavers in handloom clusters in India in general and their issues in brief, are discussed in the literature review section. The main aspect of the study attempts to discuss the overview of both these clusters related product features, techniques, and other aspects are highlighted in this section.

These two clusters of Odisha make the state to be proud in the world map for its artistic crafts with traditional garments that we drape over the body in various styles, forms and give different appealing looks in our personality. Both of them produce stoles, sarees, contemporary fashion garments, jackets, kurtas dress materials, bed-sheet, fabrics, towels, dhotis, and many more that cater to both national and international markets. They are equally competitive in terms of their products line, however, the Bargarh being the older cluster with bigger size produces a wider range of products and cater to both local and other markets whereas Gopalpur cluster provides its products primarily to the main city. These two clusters have a unique nature of production activity; Bargarh is known for cotton-based using the Ikat and Gopalpur is for Tussar silk based.

Many stakeholders are such as private entrepreneurs, designers, private bodies, and Government machinery constantly are directly or indirectly engaged with the clusters, with a purpose to change the livelihood weavers' life. However, it is revealed from some studies and Government reports that the income level and lifestyle of weaver society for the last 10 years is changed moderately as compared to other professions in India despite their hard work. Therefore, there appears to be a tremendous scope for livelihood development and entrepreneurship in the handloom cluster with the constant increasing trend of the consumers towards handloom-based sustainable fashion products.

\section{Review of literature}

The handloom sector is the main provider of bread and butter among the weavers' community in India. Since this sector is the ages of old in India, there are ample sizes of literature and studies available on this at different times. Looking at the objectives of the study, relevant and selective studies have been reviewed to get a perspective for developing a suitable strategy for suggestion and implementation. The study of Goswami and Jain ${ }^{3}$ found missing of suitable business strategy in the handloom cluster which has resulted in the effect of procurement of raw material, product planning \& promotional activities. Importantly, both handloom and handicraft sectors provide low-cost and green livelihood opportunities to millions of families as per the planning commission report (2013). ${ }^{4}$ In 1977, it was estimated that every Indian handloom offered employment to six persons. ${ }^{5}$ This indicates the role played by the handloom sector in generating employment in India. However, it has been observed that the increment of the total income of the industry does not always help the weavers to get rid of the poverty trap. There are thousands of entrepreneurs who are completely dependent on the handloom sector, but they are not from the artisans' community. The study of the Erode cluster reveals that many master artisans having more than 30 years of experience is gained managerial skills and these artisans have a better understanding of the market, leads to the success of clusters and the development of entrepreneurial skills. ${ }^{6}$ There are good business models like FabIndia, Anokhi whop, Go-coop is Indian based companies that have created a niche market for themselves and are fully dependant on the handloom sector. Similarly, the sustainable brand of international repute like Patagonia, people tree, Honest by and Mud jeans, etc are completely procuring sustainable products from the cluster. ${ }^{7}$ Further, there are many independent exporters, the Government promoted cooperative societies and state emporiums that are completely dependent on the weavers' products. But unfortunately, livelihood development and enterprise development among the weavers' community are miserable. The other issues which are affecting them in their professions such as are lack of implementation of schemes, commitment, and adequate electricity and solar light (Das, Sandhya, 2015). The entrepreneurial climate is very weak as they lack knowledge about the end market, their choices, modern business practices, physical and digital connectivity, and organized support from the agencies both Government and private. ${ }^{8}$ There are thousands of entrepreneurs who are completely dependent on the handloom sector, but they are not from the weaver's community. These entrepreneurs are acting as middlemen, some of them are independent designers who are adding further value to the artisan products to connect the niche markets. Skilled weavers having more than 20 years of experience will be capable to manage their own business in the cluster if systematic interventions and proper training can be provided in the present time. In the process, they may attempt to be become independent entrepreneurs as having requisite skills along with their organizations'-built capabilities that artisans apply freely to improve their wellbeing. ${ }^{9}$ Rural entrepreneurship implies emerging in rural areas. Institutions and individuals promoting rural development now see entrepreneurship as a strategic development intervention that could accelerate the rural development process (Saxena, 2012). Clusters and networks have been proved to be effective tools of industrial policy in developing and developed countries. This approach primarily seeks to address social and economic objectives on one side and the other; it intends to enhance the competitiveness of the handloom sector in the global platform. The world economy has witnessed that the successful apparel clusters the countries like Italy, China; Brazil, etc have credential evidence in the world business in the field of apparel and shoes. These countries have produced ample sizes of entrepreneurs (ITC, series of publications). It is also found that socio-economic indicators of weavers in the clusters are having challenges and the clusters itself requires to be revamped so that the status of weavers may develop to entrepreneurship (planning commission of Odisha). Hence, an attempt has been made to understand issues of weavers, their willingness, and the possibility to be entrepreneurship in the state.

Studies indicate that most of the weavers do not have production capacities due to poor access to finance, material, infrastructure, and market. Therefore, it has become an unattractive source of livelihood for the younger generations despite numerous interventions by the Central \& State Governments, Non-governmental Organisations (NGO), and institutions since independence. Besides, Private entities 
such as, FabIndia, designers, professionals and Tata company, etc are involved for procurement of their products and their development. To address these issues, the study here attempts to understand the various existing issues of weavers around their occupation that has become a constraint for them to become entrepreneur though, they have been practicing since long. It is observed and suggested by studies that few numbers of master weavers (traders) are already doing enterprise. Apart from this, the study aims to know their willingness to carry forward their old age profession in the future with what capacity. Further, an attempt is taken to understand Micro, Small and Medium Enterprises (MSME) and the possibility of integrating it with the cluster.

Objectives of the study: The research has attempted to study the following three areas below;

a. Aims to understand the key factors that have been historically responsible and obstruct for creating entrepreneurial opportunities for the weaver's community in the cluster.

b. To assess the possibility of integrating this cluster with the MSME sector.

c. And suggest the entrepreneurial framework for the development of clusters and welfare of weavers.

\section{Research design}

Considering the significant contribution of handloom crafts to the economy and its effect on livelihood artisan community in the clusters, the study has undertaken two handloom clusters i.e., Gopalpur and Bargarh in Odisha. In view of the pros and cons of these two clusters, exploratory research has been used using the qualitative technique. The significant insights have been observed through various studies that have given a new direction to the objectives and methodology of this study. Based on the research objectives and its requirement, both secondary and primary data have been used. The inputs from secondary sources include published reports of the Government of Odisha and India, journal articles, newspaper articles, and series of cluster study reports of students of NIFT, Bhubaneswar, have been used for understanding their problems. Stakeholders like NGOs, national awardees, retailers, entrepreneurs, designers, and active machinery of Government bodies, etc involved in the clusters have been consulted and their opinions are discussed. Primary data collection was made through field visits with discussion and observation mode concerning the issues that they are facing in the clusters. Besides, other relevant aspects which include support from the government, marketing, financial support, continuity of profession for their children in the future, etc were discussed while in the field visit. Both master weavers(traders) and weavers are categorically were contacted from both clusters while in the field visit. The total cluster societies existing in both clusters such as 12 numbers in the Bargarh cluster and 3 numbers in Gopalpur. The sample of twenty respondents from both clusters including master weavers (traders) and weavers was interviewed consist of 10 respondents belong to five societies in the Bargarh cluster and 10 respondents belong to 3 societies in Gopalpur. Their views, suggestions are recorded and documented for discussion and analysis. The focus group discussion (FGD) is used looking at their literate background, experience, convenience, recording, and motivational approach. The total number of weavers in the Gopalpur cluster is 17,000 thousand in which master weavers are 20 numbers whereas around 35000 thousand weavers in Bargarh cluster out of which 100 master belongs to that cluster.

\section{Focus group discussion}

The following set of respondents such as master weavers, and weavers were part of the interview and their views pertaining to their work-based issues appearing in the clusters and various other issues that have stopped them to be part of the mainstream in the economy. Based on their issues, perception, and credibility, the strategy is framed by to withstand government schemes like a start-up and standup and MSMEs. The entrepreneurship strategy is discussed which is exhibited in the last section of this study.

\section{Important reasons for lack of entrepreneurship development:}

1) Many of them lack a fundamental understanding of entrepreneurship. Few of them consider themselves to be original entrepreneurs as they used to make and sell the products on their own to customers directly.

2) None of the schemes introduced so far by the Central and State Government encourages entrepreneurship. The status of master weavers is yet to be given by the Government as they are operating their business in private mode (The Central Government has started working on this as per Weaver Service Center). It is one of the reasons that hinder getting financial support from the bank as well as other schemes of the Government. They primarily depend on private lenders. Apart from this, rebate on raw materials debarred from Government schemes, they shared.

3) The education level of the weavers is poor and their understanding of the end market is equally poor. Few of them were assertive and know that they are being exploited by the middlemen, but they felt helpless as they do not know the end customer as per their opinion.

4) Two members in the 1st FGD of weavers said that the Cooperative mode of production has been responsible for the exploitation of their members and that has been one of the reasons for a weak entrepreneurial climate. They feel that they are nothing but bonded weavers fully dependent upon the master weavers or wealthy and politically connected weavers from their community.

5) Three Female members in the 2nd FGD were outspoken and strongly feel that their community has been suffering because of a lack of knowledge and understanding of the mainstream market. They also feel that lack of facilities; uncertainty and risk are few important factors responsible for weavers not taking interest in entrepreneurship.

6) Two Members of the 3rd FGD strongly view that lack of education and social status are responsible for the poor entrepreneurial attitude and interest among the weavers.

7) Four members each in the next two FGDs believe that their educational, economic, and social conditions are responsible for poor entrepreneurial understanding and interest among weavers.

8) Lack of knowledge, lack of education, lack of sources of funding, understanding and exposure to modern business practices, lack of an integrated supply chain, lack of resource availability including raw material are few important reasons for a poor entrepreneurial climate. 
9) Not a single member of any of the five FGDs conducted is aware of the Start-up India Stand-up Odisha and Make in India concept and its benefits aspect. The other monetary scheme floated by the Central Government for weavers and other small traders is Mudra Scheme is a subvention in rate of interest. This is a good initiative by the Government. Many weavers have availed the loan from the bank due to rebate in rate of interest as per discussion. But due to lack of proper marketing of their products, they find difficulty to sale their entire stuffs as a result, it become difficult for them to repay the loan and get the rebate in rate of interest in a year end. Although the scheme is welcome move, however it is not helping them to run their trading smoothly. Considering their default in loan, the banks also hesitate to provide loan further.

10) Many schemes have been implemented and practiced for their skill development, economy, and social security but there is no such entrepreneurship programme initiated either by the Government or NGO or private entity. These weavers are in true sense the producer of handloom products, still, they have not realised themselves as entrepreneurs. As a result, they are not visible into the limelight of the economy.

11) One group of master weavers believe that they have strong knowledge of Tie and Dye, leadership skills, financially sound to some extent along with networking and relationship, communication skill, and self-motivated. Still entrepreneurship status is yet to be recognized.

12) Both weavers and master weavers expressed that although the Government is implementing many schemes and policies. There are still existing of corruption practices in different channels and requires to be checked.

13) Weavers expressed that the master weavers face harassment and frustration while dealing with a business with traders and agents which discourage them to keep away to start as own enterprise and also master weavers felt.

14) The absence of sufficient capital to upgrade their looms is one of the reasons to practice as an entrepreneur.

15) One weaving group suggested that good quality of training can help them to start as an entrepreneur.

16) Weavers in the cooperative societies can start as an entrepreneur but due to existence of bureaucratic structure does not permit them in one side and other side is the lack of egalitarian approach among the weavers.

17) We found that the weavers needed the experience to produce their products in their looms. Further, their lack of consistency of training holds them back from delivering supply to the demand they receive the order.

18) Weavers expressed that they are not getting recognition from the supplier of state procurement and other agencies. They want to have an independent identity from their profession.

19) The weavers lacked specialized training and to make them expertise it takes more than a month usually whereas it is not happening in that direction according to them,

20) The majority of weavers argue that their training period should be decided and monitored by the weavers' society for better results.

21) The average wages among the weavers expect the master weavers per month are Rs 8000 to 10000 in both the clusters which are just insufficient to manage a family in the present economic scenario as per their opinion.

22) All the weavers expressed that loom maintenance is becoming a difficulty for them and space factor and power cut are again other issues in the work.

Most of the members in all the 8 Focus Group Discussions in two clusters believe that lack of information, knowledge about the market, finance; poor understanding of modern business practices, corruption practices, exploitation, lack of seriousness from Government end and weak supply chain are the major reasons for the poor entrepreneurial climate in the weavers' community. It was also found that not a single weaver from the communities have registered themselves as a business entity under the Companies Act or even operating as a Sole Proprietorship.

\section{Findings and discussions}

The findings of the study are broadly discussed based on respondents' opinions and understanding and observations from field surveys which are qualitatively presented with an explanation. It was found from both the clusters that insufficient income from this occupation is not enough to manage their life smoothly. Thus, they get de-motivated to work. Secondly, many weavers are not eligible to apply for financial credit from banks due to a lack of requisite credibility. So, the local financing banks avoid paying them as it would become difficult for them to repay their debts. Lack of awareness and knowledge in the market is also one of the major reasons for which they have been exploited by the middlemen. The looms and other machinery used in the production are obsolete and are not replaced with the advanced one due to lack of support and insufficient income. Also, the attitude of weavers working under master weavers is not a professional approach that is inferred from the discussion. It is found from the discussion that weavers get payment based on completion of product and not daily basis and the amount they receive; it becomes subsistence level that makes frustration sometimes and decides for an alternative job. The marketing of the products of the cluster is also not very vivid. Most of the customers are not aware of the cluster product values and hence ignore them being happy with cheaper substitutes. Further, the younger customers, prefer to buy products from private organizations than Government-run retail outlets and cooperatives as the quality and designs provided by private players are suitable to their taste and generate a catchy storyline of the products Besides, weak marketing strategy, poor merchandising, and service are the other issues that hamper the sale of weaver products in retail outlets. One more factor affecting the weavers is the availability of pirate ikat fabric in the market and cheaper products, it becomes tough challenges for weavers to sell their hard-working quality products market, and sometimes it gets delay in sales. These are cumulative issues that discourage the weavers. It is also observed that due to the lack of weavers' fundamental understanding of the market, adequate education, exposure, laziness, and poor professionalism ultimately find their products tough challenges in the market. As a result, the growth of living standards becomes sluggish and the economic progress of weavers is yet to flourish in both the clusters. Hence, adequate and 
necessary measures are expected from all the stakeholders. Coming to support from the government, there are many drawbacks. Weavers are not happy with the Government-run retail outlets as they receive late payment sometimes from the sale of the products and hence, have poor faith in Government selling portals. Further, these outlets sometimes keep their quality products unnoticeable in the assortment due to some reasons, as a result, it is sold with heavy discounts and get the undue value of the products. According to the opinion of weavers, sometimes, they do not get timely information from the Government bodies to showcase and sell their products in the exhibition and trade fair. In this context, particularly master weavers, entrepreneur weaver, skilled weavers with educated and national awardees are more involved with the government in selling their products to big private retailers in tier $1 \& 2$ cities with huge margins and they also get orders from private retail players along with supports like design support and transport responsibility, etc. In this way, weavers save their transport costs, time, and physical and mental stress. The study also identifies that some smart weavers supply poor quality of products to Government retail outlets in the pretence of quality as a result, the image of the outlet gets damaged. to work with the Government-run retailers and they become upset with their profession which ultimately affects their economic well-being. Hence, these issues also need to be addressed to bring out the best in the cluster.

\section{Lessons for clusters and Stakeholders}

i. Emergence of Liberalization

ii. Technology

iii. Fashion \& its influence

We all have witnessed all these areas emerged in the $21^{\text {st }}$ century. Therefore, both weavers and stakeholders must take into account to establish their products in a competitive market as a unique identity and have a good value from the customer. It appears in the fact that the consumption pattern of consumers has changed significantly for the last decade. They have money and are ready to dispose of it. The problem lies in weaver's mindset that they have to show their enthusiasm, make their products stronger, better, and unique in a fast-moving society. The first and foremost role of the weavers in the clusters should try to be independent rather than completely dependent with expectation and support from the Government subsidies or welfare schemes. It is necessary to have the following criteria to make

Table I Future entrepreneurships strategies for clusters the cluster stronger;

\section{A. Mutual understanding \\ B. Make independent cluster \\ C. Market independently}

To achieve all these aspects, the weaver's community should spend at least 8 hours working a day. By developing and adopting new designs collectively will give the cluster advantage and an identity. The price of the products should not be compromised with the customers otherwise they may think in another way and the sanctity of the product will be lost. Each product should be framed with a storyline and its process mechanisms as expected by the customers to know. Product innovation must be a sustainable way as per the market demands. In globalization and technological age, the entire stuff requires to be digitized and reached to the customers through the help of the mobile app, website and using other social media platforms. By adopting new technology and channels, the clusters can create a B2B value chain. It is essential as 50 percent of the population is below $25 \mathrm{yrs}$ and 35 percent is below $35 \mathrm{yrs}$ old globally, these two segments are the active users of the internet and enable them to access the products. The most advantage of using digital platforms like e-commerce and social media, not only the weavers can reach easily to the customers easily but the involvement of middlemen in the process may be eliminated.. It is observed that the majority of the weavers are using smartphones, it is time for them to go for the digitization of products with the help of proper training provided by the Government and stakeholders. I may unquote "Hope is mankind's greatest weakness \& greatest strength".

\section{Possibility of entrepreneurial strategy}

After understanding all the aspects that have been discussed, the study proposes a framework that may be suitable for weavers in the clusters and how they can be able to establish themselves as entrepreneurs. This framework may be useful to a large extent if the Government and other stakeholders may attempt to implement all these gears of strategy in the clusters. It is expected that the clusters perhaps may become stronger, creates opportunities for the weavers, and will have a wider identity and independence in the market (Table $1)^{10-19}$

\begin{tabular}{ll}
\hline Strategy & Focus \\
\hline $\begin{array}{l}\text { Quality Educational set up at } \\
\text { proximate area }\end{array}$ & $\begin{array}{l}\text { Lead to up-skill, higher literate rate changes their mindset and help them to understand the } \\
\text { domestic and international market requirement. Also, encourage them to continue their old age } \\
\text { craft profession by maintaining both traditional to contemporary techniques. }\end{array}$ \\
$\begin{array}{l}\text { Setting up locally procurement } \\
\begin{array}{l}\text { Fabric Hub and Training center } \\
\text { This may cater to the faster availability of yarn and raw materials at a reasonable price with good } \\
\text { quality both weaving and making finished products in a hassle-free. Also, reduce the lead time in } \\
\text { (Technology Intervention) }\end{array}\end{array} \quad \begin{array}{l}\text { supply chain activity and fulfil the market requirement by attending training regularly. } \\
\text { demands across the segments. It provides zero defects in production and no effect on the } \\
\text { environment. }\end{array}$ \\
$\begin{array}{l}\text { Introduction of Digitisation } \\
\text { products and the use of social } \\
\text { media platforms }\end{array}$ & $\begin{array}{l}\text { Provide wider audience \& connectivity, understanding competitive strategy, staying connected with } \\
\text { consumers and potential consumers, understanding consumer preference. This process may lead } \\
\text { to helpful to weaver's community as well as better business. }\end{array}$ \\
\hline
\end{tabular}


Table Continued

Strategy

Focusing Emotional and emphatically aspects of fashion products

Garment driven growth

Cluster society

Cluster Identity

Being cost competitive

Community Development Center (CDC)

Collaborative work \& Research Support

The startup, stand up mode and MSME mode

Importance to Pull Supply Chain strategy instead of Push strategy in the cluster

Emphasis on Direct customer link

\section{Focus}

The store line is a must for each product that will create a feeling of connectivity \& interest among customers. Also, the printing of the environmental issues on apparel with some relevant themes in a disruptive society may add on effect. The product developed in the cluster releases low carbon emission, low energy requirement, environment friendly, uniqueness, and sustainability may influence customers mind.

In a fast-moving and growing economy like India, it becomes easy to cater to the domestic market rather than looking at the international market. This becomes an opportunity as the world market is pitching sustainable products, which will lead to higher demand globally.

The society should ensure that each weaver is provided with raw materials, dying, printing and other facilities etc. To ensure that all are getting qualitative training. Many reputed institutes in the fashion line may be deployed to promote the society. The availability of a trained workforce and marketing education may be streamlined. Leadership and team-building activities among the weavers may bring ownership and feeling of the association will make the cluster society stronger.

Various marketing concepts lead to branding by using film and other famous personalities.

Adopting new operational technique with the modernization of looms make the handloom products cost-competitive globally.

More CDC facilities in modernization form in cluster society may encourage weavers to access easily, develop new designs, and spend more time in looms. Providing measurement machine further in CDC to check quality of fabric \& product etc.

Enable the cluster financially sound, get new ideas, innovation, exposure, and design support.

Enable them to access the government financial schemes and recognition as sole proprietorship or partnership

The cluster currently operates on push supply chain format where products are first produced by the weavers and then they try to sell them to retailers due to which many products remain unsold. This needs to be changed to pull strategy of the supply chain where design and material requirements placed by the retailers as per consumer demand needs will be produced by the weavers. This decline the textile wastage as well as save the time, energy, and materials that the weavers put into production.

The practice is happening B2B where weavers are not getting good margins. If weavers can be connected with customers directly with new channels, they may able to make good money

\section{Conclusion and suggestion}

Handloom being sustainable is always remain acceptance in our society. Both Bargarh and Gopalpur clusters of Odisha produce good quality kinds of stuff with a wider variety cater to national and international markets. Therefore, it has also significant contributions to the Indian economy as a craft. Despite their positive aspects, the weavers' livelihood and their handloom journey are yet to be established and brought to the mainstream of the economy, in spite of many interventions by the Government from time to time. The study identifies various issues through observations and shared by the weavers, which are discussed in the main part of the study. The policymakers need to understand their concern that affecting the working environment and should take suitable remedies for cluster development and their welfare as well. The policymakers should provide entrepreneur status to master weavers or entrepreneurs' weavers those who are already into the enterprise so that they would become eligible to access easily bank finances and other benefits from the government. Although the Government has introduced both startup and stand-up schemes in recent times, encouragement and easy accessibility with flexibility criteria may be brought. The study also suggests that under MSME schemes, entrepreneur weavers may be brought under it so that they would become eligible to get financial credit and other benefits and entrepreneur status. In this context, the Government should play a vital role in implementing schemes and need monitoring. The study has proposed a model for the entrepreneurial strategy for weavers for policymakers which may change their life. Although these two clusters have some stability, quality parameters 
should not be deteriorated and the weavers must be prepared to accept new designs, update with new trends and understand the market requirement, participate in visit/fairs. As the target market of cluster products is niche and to some extent mediocre segment due to expensive, it is suggested that new design and production process has to be evolved by using technological supports, advanced looms, and other new mechanisms so that large quantity can be produced with cost-effective way. Academic and research institute should share their research idea to weavers regarding the fashion trend, consumer interest, and other merchandising elements. Motivational training is also important for them. To address all their issues, motivational training is important for them. Considering the findings, the study may conclude that weavers could have a better livelihood in the future if they change the outlook of their work and educate themselves as well as their future generations and the possibility of entrepreneurship is high.

\section{Acknowledgments}

None.

\section{Funding}

None.

\section{Conflicts of interest}

The authors have no conflicts of interest regarding the publication of this paper.

\section{References}

1. Annual report 2016-17. Ministry of textiles, Government of India.

2. Bhagavatula Suresh. The working of entrepreneurs in a competitive low technology industry: The case of master weavers in the handloom industry. NS Raghavan Centre for Entrepreneurial Learning (NSRCEL), Bangalore: Indian Institute of Management; 2010.

3. Goswami Rachna, Jain Ruby. Strategy for development of handloom industry. Global Journal of Finance and Management, Research India Publication. 2014;6(2):93-98.

4. Planning Commission. 12th five-year plan (2012-17). Economic Sector. 2013;2:396-397.

5. Chatterjee Ashoke. India's handloom challenge: anatomy of a crisis. Economic and Political Weekly. 2015;1(32).
6. Kumudha A, Rizwana N. Promotion of handloom product with special reference to handloom weavers' co-operative societies in erode district an empirical study. Namex International Journal of Management. 2012;2(1).

7. Panwar Tarun. Sustainable fashion business model designs. Beijing, China: IFFTI Annual Conference; 2016.

8. Rakhim KV. Traditional handloom of India: The role of the designer into market opportunity recognition in the globalization era. International Journal of Emerging Research in Management \&Technology. $2015 ; 4(4)$

9. Strawn S, Littrell M. Beyond capabilities: a case study of three artisan enterprises in India. Clothing and Textile Research Journal. 2006.

10. Goswami Omkar. Indian textile industry, 1970-1984: An analysis of demand and supply. Economic and Political Weekly. 1985;20(38).

11. Gupta N. A story of (foretold) decline: artisan labour in India. Brooks World Poverty Institute. Working Paper Series 156, UK: University of Manchester; 2011.

12. Jena BB, Tarai S. Half backed initiatives: participatory approach to development of craft cluster. International Case Symposium on Fashion, Retail \& Management (ICSFRM), Bhubaneswar: National Institute of Fashion Technology; 2015.

13. Madison Angus. The world economy. OECD Publishing; 2006.

14. Moorthy Kan. Theory and practice of handloom schemes-a review. All India Weavers Congress; 2014.

15. Planning Commission Report. Draft consultation paper on handloom, Government of India. 2014.

16. Rizwana M. Analysis of pricing strategies of handloom product with reference to weavers' cooperatives society. International Journal of Management and Social Science Research Review. 2016;1(28).

17. Sen A. Development as freedom. New Delhi: Oxford University Press; 1999.

18. Sen Mou, Saha Goutam. Developing artisans in Indian handicraft sector: an inclusive approach. CBS Journal of Management Practices. $2015 ; 2(2): 29-40$.

19. Government of India, ministry of textiles, annual report 2016-2017. 